\title{
1 \\ Departures and Arrivals in Touring Pacific Cultures
}

\author{
John Taylor and Kalissa Alexeyeff
}

\section{Reframing perspectives in tourism studies}

A Hawaiian Airlines flight from Honolulu has just landed at Kona International Airport on the Big Island, Hawai'i. Arriving passengers make their way across the tarmac and into the airport building, while those about to board the aircraft check in. In the buzzing terminal building itself, under the shade of a large, open-air roof inspired by local indigenous architectural forms, ${ }^{1}$ people and luggage are everywhere. Negotiating the bustle, bumping into benches, rubbish bins, racks of postcards and each other, they make their way from plane to bus, taxi or car, vice versa, or from one flight to another. Others anticipate arrivals, to be greeted with hugs and tears, or silently await departure calls as they sit reading, stand alone, or cluster in chatty groups. Some appear easily recognisable as touring types: a young ukulele-strumming backpacker is a case in point, as is a group dressed in business suits and greeted with handshakes and flower leis by a similarly attired delegation. A travelling dance group, evidently departing, is also recognisable by their matching t-shirts and lava-lavas. Otherwise, it is difficult to distinguish businessperson

1 Winner of the US Federal Aviation Authorities' ‘Beautification Award' for 1971, the Keahole Airport was described as a 'unique cluster of terminal structures resembling a Hawaiian village' and praised for its 'delightful melding of ancient with modern'. See 'Hawaii aviation: An archive of photos and historic facts', n.d., hawaii.gov. 
from leisure-seeker. Those idly browsing the postcard racks or the gift shop souvenirs - tiki figurines and bottle openers, fridge magnets with images of volcanic lava flows and palm-fringed beaches, hibiscusprint bags - are as likely to be locals as tourists, or may be both, departing or returning home.

At the centre of all this activity, surrounded by a concrete bench edging a small square of raised lawn, stands a beautiful life-size sculpture in bronze - three hula dancers held in an eye-catching twirl. 'Just as the hula was built on a symbolic language of gesture and movement', as the plaque describes it, one group of travellers takes turns posing for photographs with the sculpture, mimicking the dancers' pose to produce a neatly choreographed snapshot moment. Evidently providing inspiration, they are followed by another group, one of whom asks a stranger to take the shot so the entire party can be included. This casual exchange is disrupted by an elderly couple who sit on a bench in front of the dancers, an unwittingly stifling act that has the effect of creating more space for arrivals and departures to flow and bump through the terminal. At last the couple rises at the sound of a final boarding call, and as both arrivals and departures depart, a quiet descends on the terminal and finally a roar of engines signals that the passenger jet has taken to the sky once more.

This scene is mundane in many respects to airports across the island Pacific, be it Rarotonga, Luganville or Pape'ete, and introduces the central metaphor that connects the contributions of this collection. Touring Pacific Cultures explores the incessant traffic in everyday items, people and performances of cultural production, consumption and exchange that have come to define the Pacific region, and the movement of the Pacific in the world. Here we are concerned with the myriad intersections inherent to the mobilities of people and creative culture across the Pacific and beyond; arrivals are threaded with departures, locals become tourists, and culture tours at the same time as it is toured.

This book takes us on a bumpy journey, exploring how culture is defined, produced, experienced and sustained through tourismrelated practices. In doing so, it captures the importance of tourism to the visual, material and performed cultures of the Pacific region. 'Touring' is here approached in the plural sense of diverse cultures toured across multiple locales by equally diverse and cultured tourists, and also includes the travel of people and things on tour. This volume highlights the connections between tourism and other motilities and 
modalities, including the global movement of people, ideas, images and objects, the experience of class, status mobility and corporeal movement, and the ongoing importance of historical legacies to contemporary production, exchange and encounter.

The stylistic approach adopted here illustrates the complex and overlapping contours that comprise touring Pacific cultures. As such it includes a diverse range of written and visual strategies. The intention is not simply to subvert the conservative textual and analytic techniques of mainstream tourism studies, found especially in the majority of international academic journals where there is a continued reification of tourism as a simply identifiable set of practices. Despite the acknowledgement in tourism studies of an everwidening set of touristic sub-genres - such as 'eco-tourism', more recently 'dark tourism', ${ }^{2}$ medical tourism, ${ }^{3}$ film tourism, ${ }^{4}$ culinary tourism, ${ }^{5}$ sports tourism ${ }^{6}$ and voluntourism ${ }^{7}$ - such diversions into niches, ${ }^{8}$ we argue, fail to capture the diffuse, multi-faceted, fractured and elusive nature of the ideas, practices, values and processes tied up in that core concept, however tightly or loosely.

Here we have invited authors to examine the production, performance, movement and exchange of culture across and beyond the Pacific region in such a way that keeps in mind the idea of and material reality of a tourism industry, however historically inchoate, analytically slippery, or politically, socially and economically fragmented such an entity might be. In doing so, it has been possible to refocus our optics in such a way that recognises that culture often tours or is toured through contexts and for reasons that have very little to do with reified notions of 'tourists', 'tourism' or a 'tourism industry'. While recognising such intersections and departures, we have not

2 John Lennon and Malcolm Foley, 2000, Dark Tourism: The Attraction of Death and Disaster, London and New York: Continuum.

3 John Connell, 2006, 'Medical tourism: Sea, sun, sand and ... surgery', Tourism Management 27(6): 1093-100.

4 Sue Beeton, 2005, Film-Induced Tourism, Series: Aspects of Tourism 25, Clevedon: Channel View Publications.

5 Lucy M. Long (ed.), 2010, Culinary Tourism, Lexington: The University Press of Kentucky.

6 Mike Weed and Chris Bull, 2012, Sports Tourism: Participants, Policy and Providers, London and New York: Routledge.

7 Stephen Wearing and Nancy Gard McGehee, 2013, 'Volunteer tourism: A review', Tourism Management 38: 120-30.

8 Marina Novelli (ed.), 2005, Niche Tourism: Contemporary Issues, Trends and Cases, Amsterdam and Sydney: Elsevier. 
and do not advocate for a rash discarding of the notion of tourism. In fact, at very least, the very notion of tourism can be seen to act as a powerful ideological category or trope - or rather set of tropes - such that are as fundamental (and therefore unavoidable) to scholarship as they are to public discourse. There is something of a double irony in that as many leisure travellers and sightseers seek to move beyond or reject 'tourist' as a category of identification, they often tend to both reinforce and epitomise it. Through their repetition such tropes become endlessly sedimented as a 'self evident essence', ${ }^{9}$ echoing through tourism statistics, national branding campaigns, and indeed in academic research centres and projects in the still burgeoning field of tourism studies. In the same way, depending on the particular example at hand, a focus on touring Pacific cultures may lead to both reifications and disruptions of the standard tropes of tourism and tourism studies for the Pacific. This is the same in academic analyses as it is in everyday life. In one context, for example, the idea of the Pacific as paradise may be eagerly repeated by Pacific Islanders. In others it may be vehemently rejected as a neo-colonial lie, one that says nothing of the many contexts of inequality and alienation that often travel hand-in-hand with tourism-related developments.

In short, the schisms and debates of tourism studies are also evident across local productions, performances and analyses. For this reason, we have invited a range of contributions to this volume - this includes identifiably academic offerings as well as those that are less so; personal reflections, poems, artwork, images and other creative engagements. In doing so, we hope to reflect the mobile and fragmented qualities of tourism's relations to touring Pacific cultures, as well as the creative and dynamic nature of production, exchange, performance and experience that such intersecting contexts, departures and arrivals entail.

9 Chris Rojek and John Urry, 1997, Touring Cultures: Transformations of Travel and Theory, London and New York: Routledge. 


\section{Touring Pacific imaginaries}

Mobility, by definition, is a central aspect of both tourism and touring. It has, however, been curiously absent from many analyses that have instead tended to focus on static 'destinations'. One way we may critically reframe and refocus tourism-related research is by paying attention to such mobilities. This includes by observing the ways in which the material content and imagery of tourism moves and shifts, even as it is reproduced and consumed by people. As is widely noted, for many western tourists the Pacific is an imaginary awash with iridescent waters, white sandy beaches and curvaceous women reclining under swaying palms. Such highly gendered and romantic images of the Pacific as 'paradise' stretch as far back as those early 'voyages of discovery' that also arguably represent the first touristic excursions into the region. ${ }^{10}$ So, too, do titillating images of savage cannibalism, sorcery and heathen gods. While pre-colonial Pacific Islanders undoubtedly also travelled near and far for reasons primarily or partially relating to pleasure, if not leisure, the particular historic and ongoing association of tourism with various forms and products of colonialism is a defining feature of that industry. ${ }^{11}$

10 Bernard Smith, 1960, European Vision and the South Pacific (2nd ed.), New Haven: Yale University Press; Bernard Smith, 1992, Imagining the Pacific: In the Wake of the Cook Voyages, Carlton: Melbourne University Press at the Miegunyah Press; C. Michael Hall, 1998, 'Making the Pacific: Globalisation, modernity and myth', in Destinations: Cultural Landscapes of Tourism, ed. G. Ringer, pp. 140-53, London and New York: Routledge; John Connell, 2003, 'Island dreaming: The contemplation of Polynesian paradise', Journal of Historical Geography 29: 554-81.

11 See Miriam Kahn, 2011, Tahiti Beyond the Postcard: Power, Place, and Everyday Life, Seattle: University of Washington Press; Jane C. Desmond, 1999, Staging Tourism: Bodies on Display from Waikiki to Sea World, Chicago: University of Chicago Press; Hall, 'Making the Pacific'; Margaret Jolly, 1997, 'From Point Venus to Bali Ha'i: Eroticism and exoticism in representations of the Pacific', in Sites of Desire, Economies of Pleasure: Sexualities in Asia and the Pacific, ed. Lenore Manderson and Margaret Jolly, pp. 99-112, Chicago and London: University of Chicago Press; Haunani-Kay Trask, 1993, 'Lovely hula hands: Corporate Tourism and the prostitution of Hawaiian culture', in From a Native Daughter: Colonialism and Sovereignty in Hawai' $i$, pp. 17997, Maine: Common Courage Press; Tracey Banivanua Mar, 'Performing Cannibalism in the South Seas', this volume; John Connell, 'Fiji: Reflections in the Infinity Pool', this volume; Marata Tamaira, 'Native Realities in an Imaginary World: Contemporary Kānaka Maoli Art at Aulani, A Disney Resort \& Spa', this volume; John Taylor, 'Pikinini in Paradise: Photography, Souvenirs and the "Child Native" in Tourism", this volume. 
TOURING PACIFIC CULTURES

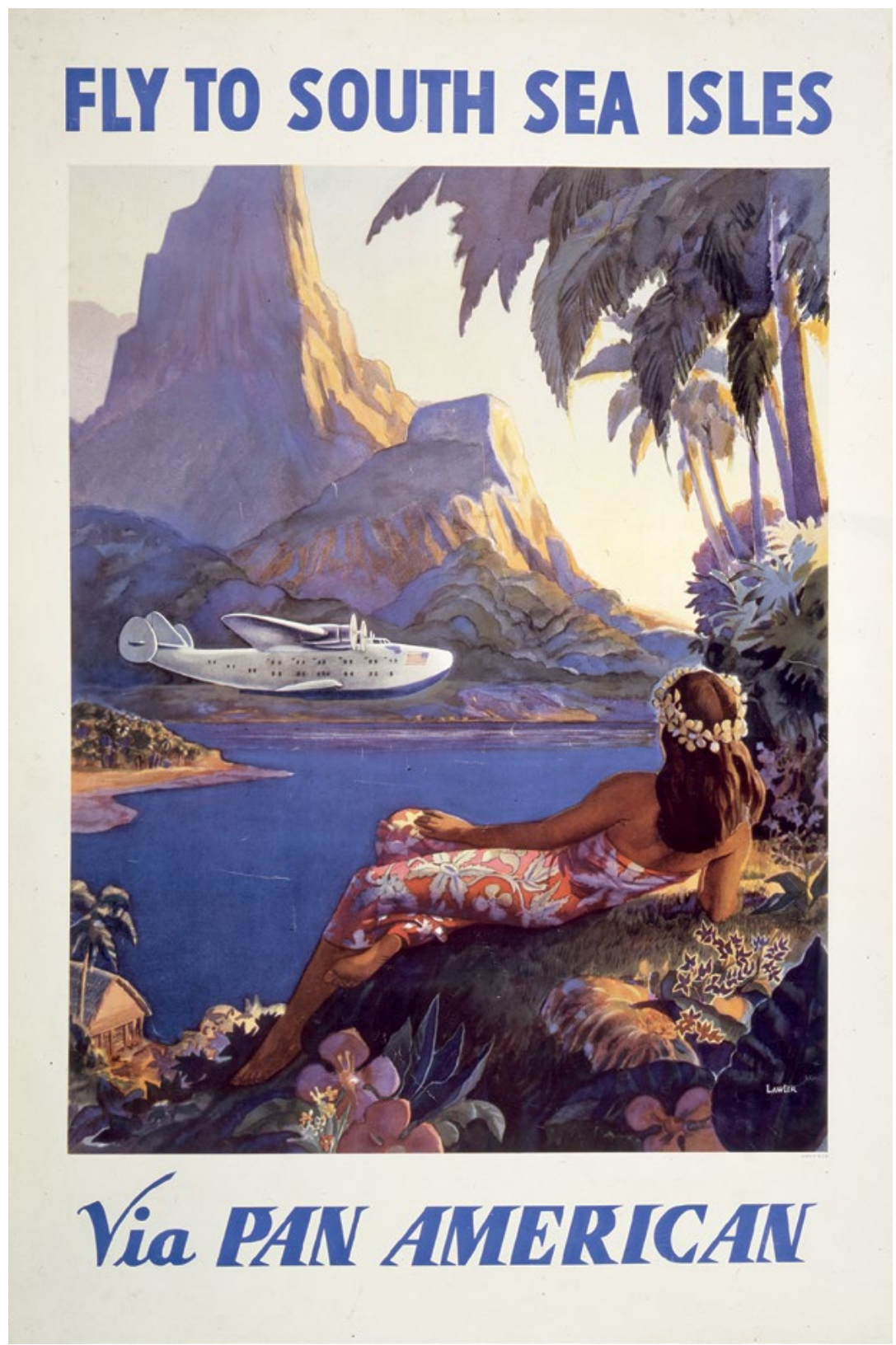



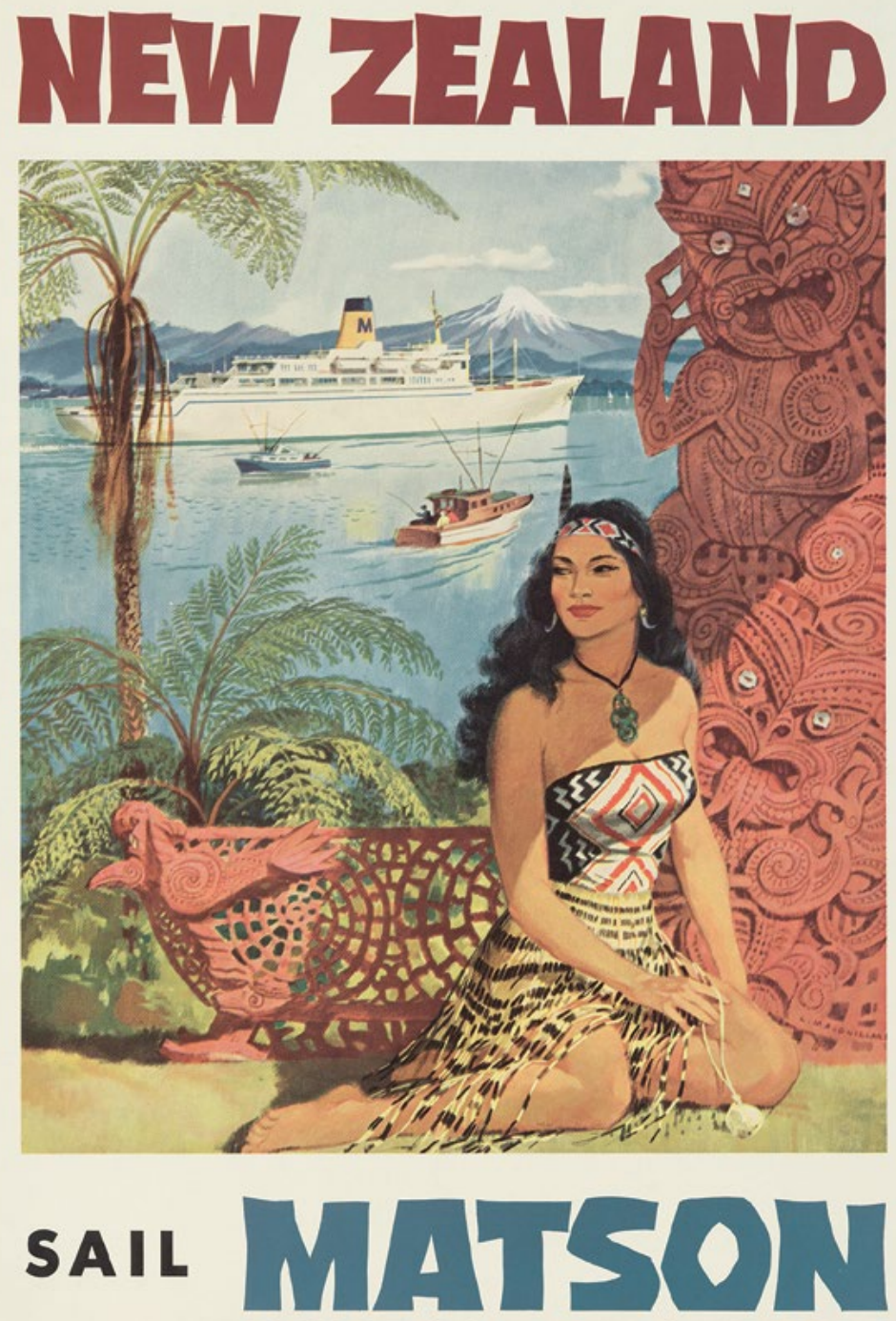

sSMARIPOSA.sSMONTEREY

Figures 1 and 2. Reclining dusky maidens provide a tranquil frame for the romance of travel for leisure, and through the important inclusion of tourism technology and infrastructure, fantasy meets reality through the prospect of touring.

Source. Figure 1. 'Fly to South Sea isles via Pan American'. Lithograph by Paul George Lawler circa 1938, Library of Congress Prints and Photographs Division Washington, DC 20540 USA; Figure 2. Louis Macouillard artwork circa 1955, reproduced courtesy of Matson. 
Many of the chapters in this volume reveal the work that has gone into creating these tropes, particularly in the nineteenth century. Mission imagery of the Pacific in the form of pictures, popular literature and lantern slides, toured metropolitan markets and, as Lamont Lindstrom shows, ${ }^{12}$ created portraits that shaped and framed perceptions of the Pacific Islands and the nascent colonial tourist industry. On the early cruise vessels of the nineteenth century, Frances Steel argues, ${ }^{13}$ cross-cultural encounters aboard ship were often unpredictable engagements that sometimes served to dismantle dominant tropes and their inherent opposition between savage and civilised, native and modern, toured and touring. This, it may also be noted, is a constantly recurring effect of the disjuncture between touristic imaginaries and real-world encounters everywhere. ${ }^{14}$ The work of artist Yuki Kihara is a contemporary intervention that serves to unveil and disrupt the racialised and gendered genealogy of colonial tropes of travel. ${ }^{15}$

Despite such disjunctures, there is a remarkable historical 'durability' of colonially produced images of the Pacific. ${ }^{16}$ Branding styles may disappear and mediums of communication change, but the images of 'soft primitivism' associated with leisure-related travel in the Pacific have for the most part remained remarkably consistent over time. While recent marketing strategies have dictated the generation of new themes within, due to an incessant replicability and 'pseudo-individuation' ${ }^{17}$ of the core touristic tropes, there remains a remarkable consistency of content across these. So in the post-war period the image of a native maiden reclining above a sandy beach and native village served equally well for Tahiti as it did for Hawai'i, and was also used more generally to represent the entire South Sea Islands. In key stylistic terms, with the replacement of mode of transport to that of accommodation, it was even extended to the snow-capped peaks of New Zealand.

12 Lamont Lindstrom, 'Darkness and Light in Black and White: Travelling Mission Imagery from the New Hebrides', this volume.

13 Frances Steel, 'The Cruise Ship', this volume.

14 Kalissa Alexeyeff, 'Re-purposing Paradise: Tourism, Image and Affect', this volume.

15 Mandy Treagus, 'Yuki Kihara's Culture for Sale and the History of Pacific Cultural Performance', this volume.

16 Desmond, Staging Tourism, p. 11.

17 Max Horkheimer and Theodor W. Adorno, 1944, Dialectic of Enlightenment, New York: Herder. 


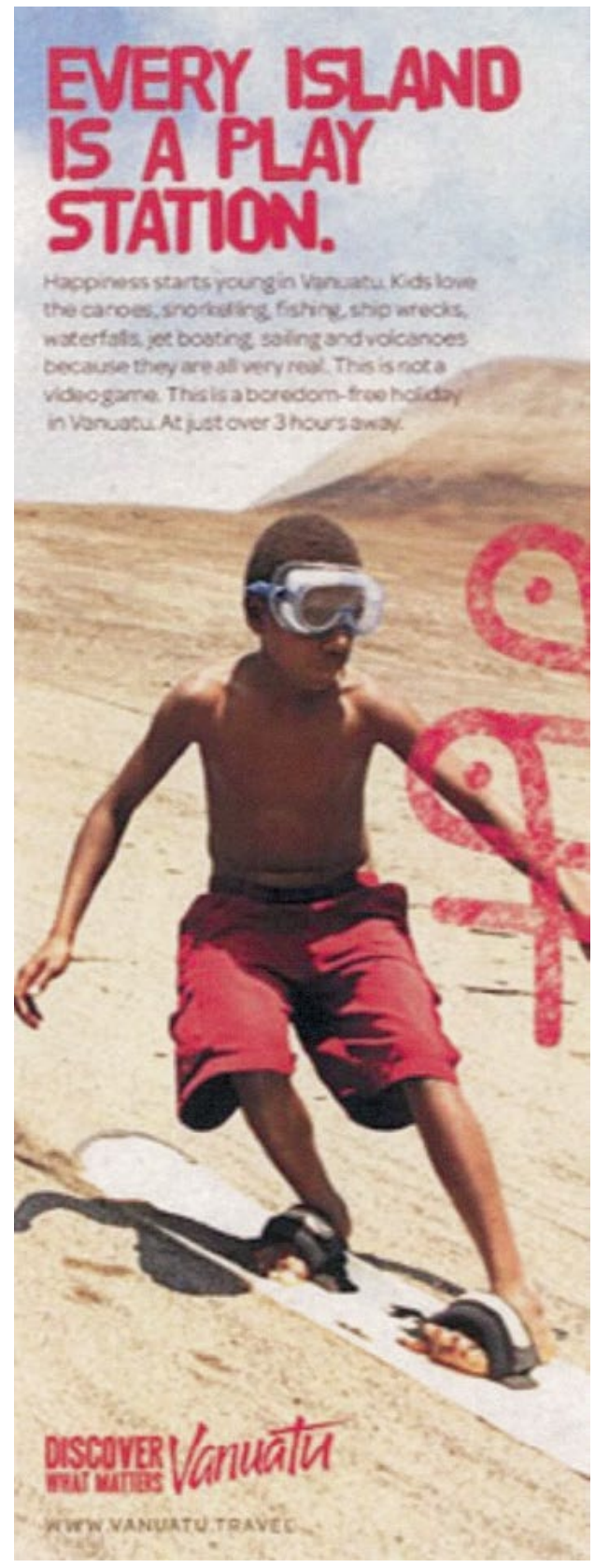

Figure 3. Images of childlike fun speak to touristic fantasies of escape from mundane life while also echoing primitivist tropes of native innocence and spontaneity.

Source. Reproduced with permission of the Vanuatu Tourism Office, 2015. 
The most recent 'rebranding' of Pacific neighbours Vanuatu and Fiji, under the respective campaign themes of 'Discover What Matters' and 'Where Happiness Finds You', demonstrate an equally remarkable interchangeability. Focusing heavily on images of frolicking indigenous children, often pictured in joyous play with tourists, both emphasise a quirky sense of childlike fun as the basis for what are simultaneously physical and existential journeys of discovery. While diverging in some respects from earlier images in terms of visual content, including by abandoning the image of the 'dusky maiden', the emphasis on carefree spontaneity represents a continuation of longstanding tropes of native primitivism measured in relation to western modernity. Such approaches also illustrate the historical durability of Polynesian-Melanesian divide in touring tropes. The romantic and bountiful 'Polynesian' princess versus the childlike or, as a flipside, the menacing cannibal that characterise 'Melanesia', have a long historical trajectory as a number of papers in this volume demonstrate. ${ }^{18}$

In considering the mobility of such images we also note the way in which visual tropes frequently slip out of the tourism sphere, featuring on products as diverse as cigarettes, beer and perfume. As the caption of one such product reads:

Sun, sea, sand, palm trees ... Sounds idyllic, right? Well, now you can escape to your own tropical paradise with the lush, exotic scent of the NEW Fijian Water Lotus range from The Body Shop. ${ }^{19}$

Touristic tropes and images relating to Pacific Island romanticisms not only migrate between 'products', they also seep into social contexts not typically associated with the tourism industry. This includes being appropriated as markers of identity or foci of critical engagement by Pacific Islanders themselves, as several inclusions in this volume examine. The dangerous warrior and the demure maiden are continuously 'played up' and both adopted and adapted in engagements with tourists. ${ }^{20}$ At dance shows across the region, emcees describe local women as 'the most beautiful in the Pacific' and jokingly warn tourists

18 Banivanua Mar, 'Performing Cannibalism in the South Seas'; and Lindstrom, 'Darkness and Light in Black and White'.

19 International, T.B.S., 2013, 'Paradise beckons with Fijian Water Lotus!' The Body Shop.

20 For example, Michelle MacCarthy, "Touring "Real Life"? Authenticity and Village-based Tourism in the Trobriand Islands of Papua New Guinea', this volume; and Taylor, 'Pikinini in paradise'. 
to avoid late night walks lest they are captured, cooked and eaten. ${ }^{21}$ Such 'appropriations' might in the former case seem ironic given their colonial legacy. Doubly so in the case of the nostalgic and nationalistic revaluing of vintage tourism advertising as 'kiwiana', and its transformation into coffee table art. Either way, such associations often suggest strong continuities across colonial and neo-colonial practices of objectification, production and capitalist enterprise.

Given the explicit centrality of mobility to tourism and touring, it is unsurprising that the depiction of modes of transport is so prominent in much tourism advertising. As such, it is not just romantic visions of 'destinations' and their inhabitants that have characterised tourism-related imagery. Equally from the outset, ships and later aeroplanes have also frequently featured as central visual components. Such inclusions reflect that the experience of travel by luxurious technologies of leisured motility is as saleable as the destinations themselves. This is particularly the case in the advertising of cruise ship tourism. They also, however, are often made to do the doublework of reflecting the trope of spatio-temporal juxtaposition.

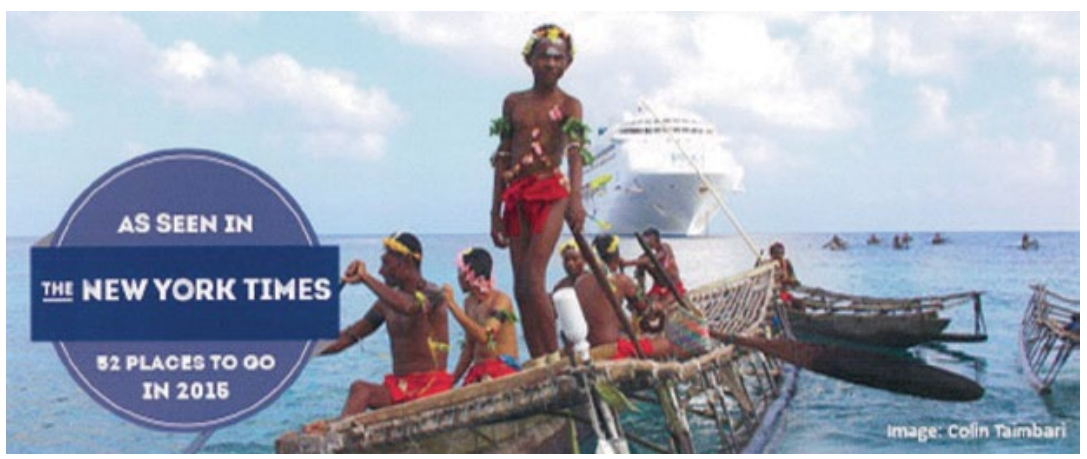

Figure 4. A long-standing favourite-images of ultra-modern cruise ships looming over 'stone age', 'primitive' or 'traditional' outriggers remain a key signifier of tourism's magical powers of transportation, such that suggest journeys through time as well as space.

Source. Photographed by Colin Taimbari and used with permission.

21 See Maria Amoamo, 'Pitcairn and the Bounty Story', this volume; and Banivanua Mar, 'Performing Cannibalism in the South Seas'. 
As several commentators have noted, in such instances the trope of paradise becomes coupled with that of nostalgia within the context of modernity. ${ }^{22}$ The implication of such narratives, of course, is that tourists may somehow uncoil the ravages of modern time and the degradations of progress. By visiting a palm-swept beach on an island in the deepest, remotest Pacific, they may also rediscover their longlost 'real' selves, reconnecting with nature and humanity alike.

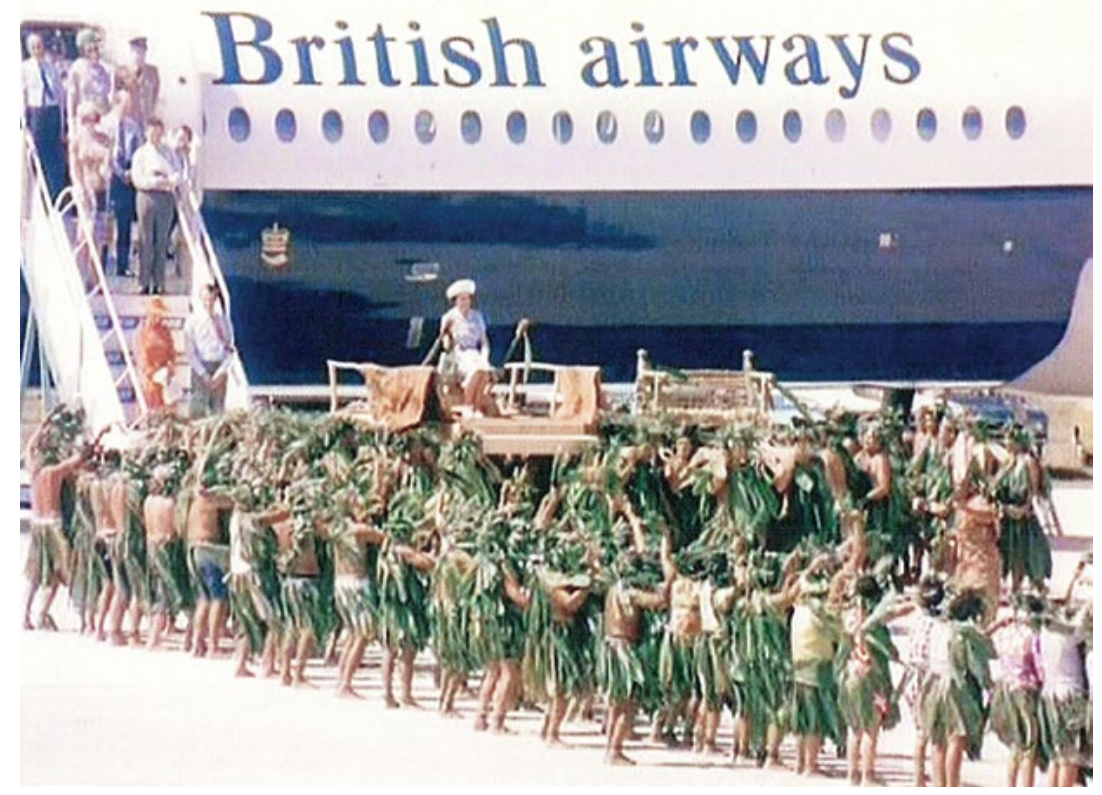

Figure 5. Typifying the nexus of tourism and contemporary colonialism, Queen Elizabeth II is given an elevated royal welcome as she arrives on Rarotonga by British Airways to officiate at the grand opening of the Rarotonga International Airport, 1974.

Source. Photographed by Bill Johnson and used with permission.

22 Barry Curtis and Claire Pajaczkowska, 1994, 'Getting there: Travel, time and narrative', in Travellers' Tales: Narratives of Home and Displacement, ed. George Robertson, pp. 199-215, London and New York: Routledge; Desmond, Staging Tourism; Catherine A. Lutz and Jane Lou Collins, 1993, Reading National Geographic, Chicago: University of Chicago Press; John Taylor, 1998, Consuming Identity: Modernity and Tourism in New Zealand, Department of Anthropology, University of Auckland. 


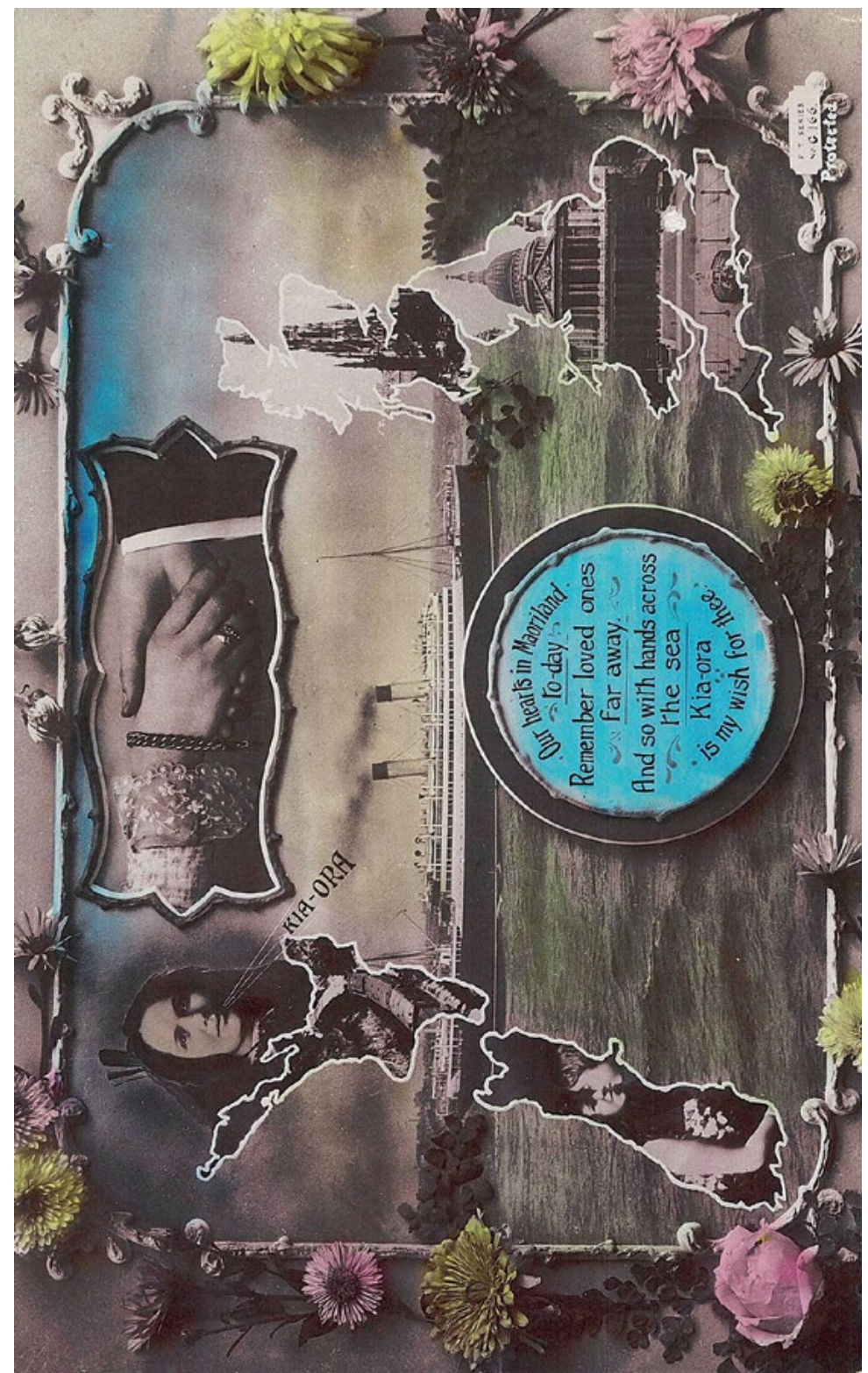

Figure 6. This example of touristic material culture and imagery can be read as being equally if not more reflective of class-related labour mobility within the context of colonialism than tourism per se.

Source. Postcard. Kia Ora. Our hearts in Maoriland today ... F.T. series No. G 166. Protected. New Zealand postcard (carte postale). Made in England [ca 1911]. Ref: EphPOSTCARD-Hearts-and-Minds-04. Alexander Turnbull Library, Wellington, New Zealand. Online: natlib.govt.nz/records/22801988 (accessed 9 March 2016). 
From the earliest days, the inclusion of ships and later planes in tourism imagery has not only played into primitivist desires and fantasies, it has also reinforced in a much more tangible sense the link between tourism and neo-colonial enterprise. This was most explicitly witnessed during the nineteenth and early twentieth centuries, during which time the first inter-island tours were offered. ${ }^{23}$ Here, as in the present, adventure-seeking travellers very often had multiple reasons for travelling, and were transported with cargo and other passengers largely dissociated from that still nascent tourism industry.

The voyages of missionary vessels such as the Melanesian Mission's Southern Cross similarly overlapped with and fed into the industrialisation of leisured travel. Indeed, both colonial and missionary writers contributed to much of the earliest travel literature. ${ }^{24}$ By contrast, in New Zealand as the postcard came to represent an instantly recognisable material signifier of tourism and circulated Orientalist fantasies of a romantic 'Maori Wonderland', intersecting nostalgias were often apparent as longings for home referenced the lived experience of long-distance labour mobility alongside those associated with touristic nativeness. In sum, it would appear the images and affective sentiments associated with tourism are as mobile and multi-directional as tourists themselves.

This volume does not attempt to provide a complete picture of the intersecting and enmeshing of tourism and other forms of mobility in the Pacific region. It does, however, demonstrate the extraordinary historical and geographical mobility of Pacific culture in the form of objects, images and imaginaries. Most particularly, Jo Diamond's chapter takes us on a mystery tour to discover the origins of the pari, the bodice worn by Maori women in cultural performances. ${ }^{25}$ This tour moves through archives, histories and images from across the globe and encapsulates the cross-currents that have created both the pari and academic disciplines that similarly tour the region: Pacific studies, anthropology and tourism research. In other chapters, many Pacific Islanders are depicted engaging in movement at very different

23 Ngaire Douglas, 1996, They Came for Savages: 100 years of Tourism in Melanesia, Lismore: Centre for Tourism, Southern Cross University.

24 Frances Steel, 2011, Oceania Under Steam: Sea Transport and the Cultures of Colonialism, c. 1870-1914, Manchester: Manchester University Press; Lindstrom, 'Darkness and Light in Black and White'; and Steel, 'The Cruise Ship'.

25 Jo Diamond, 'Writing Home on the Pari and Touring in Pacific Studies', this volume. 
registers from displacement ${ }^{26}$ and labour migration ${ }^{27}$ to travel to cultural exhibitions and workshops ${ }^{28}$ regional festivals, ${ }^{29}$ or for leisure and education. This diversity invites strategies of understanding that are equally enmeshed, mobile and multi-perspectival. ${ }^{30}$

\section{Destination inequality?}

Colonial migration, capitalist enterprise and the missionary legacy are imbricated within the dynamics and practices of tourism today. The latter for instance is witnessed in the growing trend of voluntourism that simultaneously satisfies the desire to undertake 'good works' and provides a quest for 'remote' adventure. ${ }^{31}$ Likewise, for Pacific Islanders, church and business enterprise, as with political engagement and education, represent significant contexts of pleasurable travel. In Vanuatu, the link between tourism and neocolonial enterprise is explicitly witnessed in the close association of tourism imagery and advertising with rapacious land sales, especially to expatriate Australian and New Zealander 'sea changers' ${ }^{32}$ Many of these touristic migrants go on to contribute more directly still to the presently booming tourism economy by setting up tourism-related businesses themselves.

In the most extreme cases, colonialism and tourism have intersected to both undermine and appropriate indigenous forms of cultural identity. As Marata Tamaira in her analysis of the Aulani, A Disney

26 Tamaira, 'Native Realities in an Imaginary World'; Greg Dvorak, 'Detouring Kwajalein: At Home Between Coral and Concrete in the Marshall Islands', this volume.

27 Alexeyeff, 'Re-purposing Paradise'.

28 Margaret Jolly, 'Moving Towers: Worlding the Spectacle of Masculinities between South Pentecost and Munich', this volume; Bomai D. Witne, 'A Trip from Port Moresby to Suva', this volume.

29 Katerina Teaiwa and Joseph Vile, 'New Pacific Portraits: Voices from the 11th Festival of Pacific Arts', this volume; Peter Phipps, 'Performing Indigenous Sovereignties across the Pacific', this volume.

30 Miriam Kahn, Teana Gooding and Moenau Holman, 'Cross-currents: Teana and Moenau, Tahitian Tourists in Seattle', this volume; Courtney Sina Meredith, 'Ibu \& Tufuga' and 'Great Works', this volume; and Flora Aurima-Devatine, 'Carnet de Voyage en Irlande', this volume.

31 Mary Mostafanezhad, 2014, 'Locating the tourist in volunteer tourism', Current Issues in Tourism 17(4): 381-84.

32 Claire Slatter, 2006, 'The con/dominium of Vanuatu? Paying the price of investment and land liberalisation', unpublished paper. 
Resort \& Spa on $\mathrm{O}^{\prime} \mathrm{ahu}$, Hawai' $\mathrm{i}^{33}$ demonstrates, such appropriations entail a repackaging of place and history even as the original owners, many of whom are excluded from such contexts, live in relative poverty nearby. The inclusion of indigenous agency in the production of many of these repackagings, however, ensures that they do not always appear as simple sanitisations, but may be subversively shot through with critical voices, images and perspectives. Similarly, here the analysis of such violent appropriations and erasures comprises a key feature of this volume, such that they often lead to further creative, critical and reflexive interventions. In telling the story of his family's residence on the military base of Kwajalein Atoll, Marshall Islands, Greg Dvorak uncovers layers of American and Japanese history from the half-buried bunkers, and then to the bottom of the lagoon where the remains of Japanese war dead are presumed to be located. In doing so, following in the path of both the analyst and of war pilgrims, we are taken on a tour and detour through acts of familial and ancestral memorialisation. ${ }^{34}$

Such connections not only suggest the complexly articulated nature of the tourism 'industry', they also point to ongoing processes of resource extraction and increasing inequality that have come to define tourism 'investment' and 'development' across much of the region and beyond. ${ }^{35}$ It may be the case that in the current neo-liberal climate, inequality is not only an unfortunate outcome of tourism development, but a key driving force in touristic reproduction and enterprise. At the most fundamental level, relative poverty not only provides photogenic 'added value' to tourism destinations in the form

33 Tamaira, 'Native realities in an Imaginary World'; see also Anita Jowitt, 'Suva, November ' 97 ', this volume.

34 Dvorak, 'Detouring Kwajalein'; on 'militourism', the strategic links between tourism and military, see also Teresia Teaiwa, 1999, 'Reading Paul Gauguin's Noa Noa with Epeli Hau' ofa's Kisses in the Nederends: Militourism, feminism, and the "Polynesian" body', in Inside Out: Literature, Cultural Politics, and Identity in the New Pacific, ed. Vilsoni Hereniko and Rob Wilson, pp. 249-63, Boston: Rowman and Littlefield; and Setsu Shigematsu and Keith L. Camacho (eds), 2010, Militarized Currents: Towards a Decolonized Future in Asia and the Pacific, London and Minneapolis: University of Minnesota Press.

35 Donald V.L. Macleod and James G. Carrier (eds), 2010, Tourism, Power and Culture: Anthropological Insights, Bristol: Channel View Publications; John Connell, 2013, Islands at Risk?: Environments, Economies and Contemporary Change, Cheltenham and Northhamton, MA: Edward Elgar Publishing; John Connell and Barbara Rugendyke, 2008, Tourism at the Grassroots: Villagers and Visitors in the Asia-Pacific, Abingdon: Routledge; Regina Scheyvens, 2012, Tourism and Poverty, Hoboken: Routledge. 
of exotically attired locals. It also ensures an abundance of cheap beachfront land and labour, thereby enabling the materialisation of those Pacific imaginaries of sand, sea and service.

The ever elusive promise of a significant financial 'trickle-down' ensures the continuing support of national governments for tourismrelated development, including in creating infrastructure that often benefits expatriates more than locals. As described by C. Michael Hall, 'As a destination for the tourist, the Pacific is a creation of capitalism', and as such, 'has always been a component of the global system', however that may be defined.$^{36}$ We are mindful of the critical importance of this perspective and agree that much tourism industry enterprise represents the 'hedonistic face of neo-colonialism', and thereby amounts to 'leisure imperialism' ${ }^{37}$

Leisure imperialism is not simply the purview of western tourists, it is also increasingly and ambivalently adopted by Pacific Islanders themselves. So, the island dream is not only consumed by visiting tourists but also by an expanding middle class in the region as well as in large transnational diasporic communities. ${ }^{38}$ Such multidirectionality reminds us that class location is a further component that shapes touristic engagements. The economic and cultural capital available to local elites enables them to replicate leisure practices that are out of reach to the majority of local poor. This includes visiting resorts for a massage or to socialise by the pool, and it is embodied in leisure activities such as sun-baking and swimming, both foreign concepts to many Pacific peoples for whom the beach, ocean, reef and lagoon are places of work (for example, fishing or pearling, gathering seaweed or shells for necklaces).

36 Hall, 'Making the Pacific', p. 141; see Alexeyef, 'Re-purposing Paradise'. Also C. Michael Hall and Stephen J. Page (eds), 1996, Tourism in the Pacific: Issues and Cases (1st ed., series in tourism and hospitality management), London and Boston, MA: International Thomson Business Press.

37 Malcolm Crick, 1989, 'Representations of international tourism in the social sciences: Sun, sex, sights, savings, and servility', Annual Review of Anthropology 18: 307-44; and see Connell, 'Fiji: Reflections in the Infinity Pool'.

38 See Audrey Brown-Pereira, 'Local Tourist on a Bus Ride Home', this volume; and Audrey Brown-Pereira, 'Mixed Bag of Tropical Sweets Sitting Outside the Hotel R \& R', this volume; Regina Scheyvens, 2007, 'Poor cousins no more valuing the development potential of domestic and diaspora tourism', Progress in Development Studies 7(4): 307-25. 
Tourism is known to enact and effect wealth differentials within and across communities and nations. ${ }^{39}$ Increasingly, such inequalities are explicitly defined through tourism-related engagement and conflicts within the region, including in ways that move beyond the tourist/ local divide. In the Cook Islands for example, Fijian contract workers are key to service industry provision associated with tourism as Cook Islanders choose to work abroad rather than at home. At another register, the New Zealand Government recently and controversially changed labour laws in order to bolster the international film industry, and by extension in the interests of benefiting the generation of film tourism. Even so, as in this case, it seems that the fetishistic desires and imaginaries of international tourism - whether they be of Pacific paradise or other fantasy landscapes, such as Hobbiton-often evidently overshadow such realities. ${ }^{40}$

By contrast, at a more localised level, tourism shapes cross-cultural understandings of work and leisure, notions of economic development and culture difference more generally. In this context, 'the tourist' operates as a highly ambivalent trope indexing both the promises of capitalism and the pitfalls of neo-colonial inequality. Throughout the Pacific, tourism is the focus of entrepreneurial ambitions, be it in opening a guesthouse, sewing handicrafts to sell at the airport, or purchasing a boat or taxi. Working in some sectors of the industry (such as tourist bureaus and as dancers and musicians) affords prestige if not wealth to some locals. Conversely, the term 'tourist' is used by Cook Islanders as a pejorative term to describe locals who dress immodestly or who conspicuously 'flash' around money or other signs of wealth. The numerous diasporic locals who return from Australia and New Zealand for holidays similarly embody this ambivalence. With cameras flashing, expensive clothing, and self-conscious expressions of local language and protocols, they are described, and as well describe themselves, as tourists in comparison to their local family members. By contrast, and differing once again to widely held if somewhat ambivalent beliefs about the economic benefits of tourism in the Cook Islands or Fiji, Tongans are often reticent about engaging explicitly in conventional tourism. As long as Tongans residing overseas support

39 See John Cox, 'Bandit Singsing: The Tourism Unexperience', this volume.

40 Carolyn Michelle, Ann L. Hardy, Charles H. Davis and Craig Hight, 2014, 'An unexpected controversy in Middle-earth: Audience encounters with the "dark side" of transnational film production', Transnational Cinemas, pp. 1-18. 
their national economy by making regular visits home (itself a form of tourism), tourism in the more conventional sense of hosting foreigners is considered a largely unattractive enterprise. ${ }^{41}$ As cases like these demonstrate, the trope of the tourist as well as the value of tourism is diversely and complexly constituted across the region.

Relations of gender further cross-cut engagements between 'locals' and 'tourists'. Classic analyses of tourism have rightly emphasised the role of stereotypes of 'hula girls' and 'dusky maidens' in generating a sexualised vision of the Pacific. ${ }^{42}$ Such types often relate to geographic divides, with Melanesia by contrast often being marked in more masculine terms, including through tropes of the muscular savage and smiling 'pikinini in paradise'. ${ }^{43}$ At the same time, however, we note that an awareness of gender does not only entail paying attention to the dynamics of relations between men and women, but also between different kinds of masculinities and femininities. In this way, Margaret Jolly eloquently details how the commodification of kastom and contestations surrounding the land dive in South Pentecost are enacted in a jostling performance of 'relational masculinities' between indigenous men of different status and between indigenous men and foreign men. Such insights demonstrate the ways in which gender relations are harnessed as a part of enactments and reenactments of power and authority, intersecting with class, race and other sites of social as well as economic capital.

Such analyses are vital to understanding the political-economic realities that underpin the tourism industry. However, recognising the link of tourism and other forms of Pacific touring to inequality should not eclipse an appreciation of tourism's many positive outcomes, for tourists and locals alike. Many local communities and individuals do enjoy significant financial and other forms of reward from engaging in tourism-related enterprise. Tourism-related engagements and activities also may play a key role in promoting aspects of indigenous culture. We should also be attentive to the many revaluations and relocations of tourism products that occur as a part of everyday life, both across the Pacific and beyond. Here, for example, we recognise

41 See Helen Lee, 'The Friendly Islands? Tonga's Ambivalent Relationship with Tourism', this volume.

42 Selina Tusitala Marsh, 'Hawai'i: Prelude to a Journey', this volume; Meredith, 'Ibu \& Tufuga' and 'Great Works', this volume.

43 John Taylor, 'Pikinini in Paradise', this volume. 
that locals who produce many such products - including especially forms of 'cultural tourism' - very often repurpose these to fulfil local purposes of performance and consumption. Thus the same choreographed cultural show that is produced for performance in a resort setting might also on later occasions be repurposed to welcome home returning political dignitaries, toured to a regional arts festival, or included in the program of a school fundraising event. In cases such as these, tourism is a crucial site for the meaningful engagement of ongoing strategies concerning personal livelihood, community development and the sustainability of cultural heritage.

Looked at through the lens of dynamically mobile touring culture, such that reframes tourism as an analytic category, the easy dismissal of tourism-related performances as shallowly inauthentic is rendered problematic at best, if not entirely inappropriate. As the many diverse papers of this volume demonstrate, the ascription of relative positive or negative cultural value as to the degree to which such traditions might be seen as more or less 'invented' is largely a matter of perspective. In the same way, just as tourism appears in diverse and ever changing inflections across the region, by refocusing our attention in such a way that recognises the mobile, fragmented and diffuse nature of tourism, perhaps we may find a space in which to celebrate even as we critically evaluate the performances, encounters and productions that the notion of tourism encompasses.

\section{Reframing and remobilising tourism studies}

Tourism today is vital to the economies of most if not all Pacific nations. Over many decades it has also represented an important albeit often contested site for the dynamic production and circulation of cultural practices, meanings and values. ${ }^{44}$ In tourism industry and development literature especially, extraordinary statistics linking 'visitor arrivals' to 'capacity generation' are routinely marshalled to justify the bolstering of tourism-related infrastructure across the

\footnotetext{
44 Stephen Pratt and David Harrison (eds), 2015, Tourism in Pacific Islands: Current Issues and Future Challenges, Contemporary Geographies of Leisure, Tourism and Mobility, London and New York: Routledge; David Harrison, 2003, Pacific Island Tourism, New York: Cognizant Communication Corporation; Douglas, They Came for Savages; Connell and Rugendyke, Tourism at the Grassroots.
} 
region. ${ }^{45}$ Impressive though they may be, however, these say little about the complex social, cultural and environmental costs and benefits associated with these indices. More so, they rest on a largely discursive category of 'tourism' as a monolithic whole that ignores the many intersections that cross-cut the countless practices, processes and products encompassed by that term. In reality, tourism is difficult to pin down, being complexly articulated across multiple sites of production, consumption and lived experience. ${ }^{46}$ Its diffuse yet ubiquitous reach means that tourism intersects in one way or another with the lives of all Pacific Islanders. Yet it does so unevenly. As such, the benefits and costs of tourism, however defined, are not distributed or experienced equally. In the same way, Pacific Islanders are involved in tourism to varying degrees and in different contexts. Some have daily face-to-face involvement as tour operators, hotel staff, business investors or in their roles as public servants, while others engage less directly with tourists through related industries such as farming, fishing and craft manufacture, or still more casually or sporadically as a part of day-to-day living. At the same time, clearly tourism revenues more directly benefit a minority elite, both local and expatriate.

Observations concerning the enmeshing of tourism in everyday life, and of the diffuse and fragmented nature of tourism as an industry are not entirely new. Neither are attempts to respond to such observations through deconstructing, expanding or otherwise rethinking our understandings of tourism and the tourism industry ${ }^{47}$ or broadening

45 As one example, the Pacific Islands Forum Secretariat report on Tourism as a Pillar of Economic Growth states that 'Tourism is vital to the sustainable growth of Forum Island Countries (FICs), contributing an estimated 10.7 per cent of the region's Gross Domestic Product (GDP) in 2012. In 2010 tourism accounted for 56 per cent of Palau's GDP, 44.4 per cent of Cook Islands GDP, 34.1 per cent of Vanuatu's GDP, and 23.4 per cent of Fiji's GDP. In most FICs, it continues to be the major driver of economic growth and foreign exchange earnings. The 2012 Economic Impact report by the World Travel and Tourism Council showed that total (direct, indirect and induced) contribution of tourism to the Pacific Island economies in 2012 was 2.7 per cent of total GDP (US\$46.7bn). This is forecast to rise by 1.8 per cent in 2013.' See Pacific Islands Forum Secretariat, 2013, Tourism as a Pillar of Economic Growth, Nuku'alofa, Tonga, 3-5 July, Pacific Islands Forum Secretariat.

46 See, for example, Anne Campbell, 2009, 'Almost in paradise: The intrusion of tourism in the living/leisure space of local women In Waikiki', World Leisure Journal 51(3): 160-66.

47 Sohail Inayatullah, 1995, 'Rethinking tourism: Unfamiliar histories and alternative futures', Tourism Management 16(6): 411-15; Freya Higgins-Desbiolles, 2006, 'More than an "industry": The forgotten power of tourism as a social force', Tourism Management 27(6): 1192-208; Arthur Asa Berger, 2004, Deconstructing Travel: Cultural Perspectives on Tourism, Walnut Creek: Rowman Altamira. 
the scope of tourism-related scholarship..$^{48}$ Chris Rojek and John Urry's serendipitously titled Touring Cultures: Transformations of Travel and Theory was premised on just such a project, proposing to move beyond previous visions by seeing tourism as a cultural practice that is both highly social and sensorial. Through his notion of 'traveling cultures', James Clifford has also insisted that we direct our analyses away from entrenched understandings of cultures as fixed wholes and instead pay better attention to the mobility and intermingling of people and things. ${ }^{49}$ Just as we should look beyond the boundedness of anthropological 'pure cultures', so too we should look beyond the boundedness of 'pure tourism'. Instead, we might conceptualise the culture of tourism as infinitely diverse and mobile, and as characterised by long histories of travelling and meeting, gazing and exchanging, borrowing and producing, accommodating and resisting.

Remobilising our understanding of tourism includes at a most basic level refocusing questions regarding the stereotypical image of tourists as foreigners from 'big' countries (economically if not physically) who visit remote and exotic Pacific Islands and people in order to satiate their primitivist desires and for a short time live out romantic, barefoot, sun-drenched fantasies. Equally it includes refocusing stereotypical images of locals performing culture in staged settings, trapped in a devilish and divisive pursuit of capital, such that would quench touristic fantasies even as it degrades the traditions from which those performances are derived. Approaches such as these that continue to too easily see tourism production as consisting entirely as gratuitous spectacle, as consisting of sharply defined front and back 'stages', ${ }^{50}$ or as endlessly producing a 'hermeneutic circle' of commodified culture, ${ }^{51}$ merely reify the trope of tourism. Worse, they rehearse a negative meta-narrative that casts tourists and locals alike as slaves to a Kafkaesque machine of Destination Marketing.

48 Noel B. Salazar, 2010, Envisioning Eden: Mobilizing Imaginaries in Tourism and Beyond, New York: Berghahn Books; Claudio Minca and Tim Oakes (eds), 2006, Travels in Paradox: Remapping Tourism, Lanham: Rowman \& Littlefield; Rojek and Urry, Touring Cultures.

49 James Clifford, 1997, Routes: Travel and Translation in the Late Twentieth Century, Cambridge, MA: Harvard University Press.

50 Dean MacCannell, 1976, The Tourist: A New Theory of the Leisure Class, Berkeley, CA: University of California Press.

51 Patricia C. Albers and William R. James, 1988, 'Travel photography: A methodological approach', Annals of Tourism Research 15(1): 134-58, p. 136; Erik Cohen, 1988, 'Authenticity and commoditization in tourism', Annals of Tourism Research 15(3): 371-86. 
Just as some commentators are quick to vilify tourism as an industry for its deleterious effects on local populations and indigenous cultures, for politicians and tourism industry advocates the trope of tourism is often taken as a harbinger of development and prosperity, especially for populations typically figured as 'isolated' from significant flows of capital. This is reflected, for example, in the South Pacific Tourism Organisation's ministerial vision, that 'Tourism will inspire sustainable economic growth and empower the Pacific people'.$^{52}$ Coming from the other extreme, such visions are equally problematic for conviction and dependence on the monolithic trope of tourism. Clearly, just as tourism may be more or less present in daily life, as numerous case studies demonstrate, explicit engagement with tourism may be both positive and negative in its social and economic effects. ${ }^{53}$ Just as the validity of Fiji or Vanuatu being identified the happiest country in the world ${ }^{\prime 54}$ is up for debate, even as it presents an effective tourism marketing slogan, measuring and scaling such impacts is a fraught exercise.

All such tourisms exist - happy, sad, corrosive and creative - as tropes and as material realities. But these descriptive fields are far from the be all and end all of touring Pacific cultures. Here we take seriously the simple observation that cultural products readily associated with tourism are rarely produced or consumed within the context of a discretely defined tourism industry. Neither are they toured exclusively by tourists. Tourism is not an isolated sphere of activity. Rather it denotes a loose conglomeration of political, economic and social phenomena that in reality intersect - in one way or another, be it directly or indirectly - with a great many other aspects of daily life and outcomes of material production.

52 South Pacific Tourism Organisation, 2012, Pacific Regional Tourism Capacity Building Programme (Inception Report and First Work Plan), South Pacific Tourism Organisation.

53 On this tension, see Cluny Macpherson, 2008, 'Golden goose or Trojan horse? Cruise ship tourism in Pacific development', Asia Pacific Viewpoint 49(2): 185-97.

54 Worldwide Independent Network of Market Research (WIN), 2014. 'End of Year Survey 2014', Gallup International, Zurich, 30 December. 


\section{References}

Albers, Patricia C. and William R. James. 1988. 'Travel photography: A methodological approach.' Annals of Tourism Research 15(1): $134-58$.

Beeton, Sue. 2005. Film-Induced Tourism. Series: Aspects of Tourism 25. Clevedon: Channel View Publications.

Berger, Arthur Asa. 2004. Deconstructing Travel: Cultural Perspectives on Tourism. Walnut Creek: Rowman Altamira.

Campbell, Anne. 2009. 'Almost in paradise: The intrusion of tourism in the living/leisure space of local women in Waikiki.' World Leisure Journal 51(3): 160-66.

Clifford, James. 1997. Routes: Travel and Translation in the Late Twentieth Century. Cambridge, MA: Harvard University Press.

Cohen, Erik. 1988. 'Authenticity and commoditization in tourism.' Annals of Tourism Research 15(3): 371-86.

Connell, John. 2003. 'Island dreaming: The contemplation of Polynesian paradise.' Journal of Historical Geography 29: 554-81.

_. 2006. 'Medical tourism: Sea, sun, sand and ... surgery.' Tourism Management 27(6): 1093-1100.

- 2013. Islands at Risk?: Environments, Economies and Contemporary Change. Cheltenham and Northhamton, MA: Edward Elgar.

Connell, John and Barbara Rugendyke. 2008. Tourism at the Grassroots: Villagers and Visitors in the Asia-Pacific. Abingdon: Routledge.

Crick, Malcolm. 1989. 'Representations of international tourism in the social sciences: Sun, sex, sights, savings, and servility.' Annual Review of Anthropology 18: 307-44.

Curtis, Barry and Claire Pajaczkowska. 1994. 'Getting there: Travel, time and narrative.' In Travellers' Tales: Narratives of Home and Displacement, ed. George Robertson, pp. 199-215. London and New York: Routledge. 
Desmond, Jane C. 1999. Staging Tourism: Bodies on Display from Waikiki to Sea World. Chicago: University of Chicago Press.

Douglas, Ngaire. 1996. They Came for Savages: 100 years of Tourism in Melanesia. Lismore: Centre for Tourism, Southern Cross University.

Hall, C. Michael. 1998. 'Making the Pacific: Globalisation, modernity and myth.' In Destinations: Cultural Landscapes of Tourism, ed. G. Ringer, pp. 140-53. London and New York: Routledge.

Hall, C. Michael and Stephen J. Page. 1996. Tourism in the Pacific: Issues and Cases (lst ed., series in tourism and hospitality management). London and Boston, MA: International Thomson Business Press.

Harrison, David. 2003. Pacific Island Tourism. New York: Cognizant Communication Corporation.

'Hawaii aviation: An archive of photos and historic facts.' n.d. hawaii.gov. Online: hawaii.gov/hawaiiaviation/hawaii-airfieldsairports/hawaii/kona-international-airport-at-keahole (accessed 9 March 2012).

Hereniko, Vilsoni and Rob Wilson (eds). 1999. Inside Out: Literature, Cultural Politics, and Identity in the New Pacific. Boston: Rowman and Littlefield.

Higgins-Desbiolles, Freya. 2006. 'More than an "industry": The forgotten power of tourism as a social force.' Tourism Management 27(6): 1192-208.

. 2012. 'Resisting the hegemony of the market: Reclaiming the social capacities of tourism.' In Social Tourism in Europe, ed. Scott McCabe, Lynn Minnaert and Anya Diekmann, pp. 53-66. Bristol: Channel View Publications.

Horkheimer, Max and Theodor W. Adorno. 1944. Dialectic of Enlightenment. New York: Herder.

Inayatullah, Sohail. 1995. 'Rethinking tourism: Unfamiliar histories and alternative futures.' Tourism Management 16(6): 411-15.

International, T.B.S. 2013. 'Paradise beckons with Fijian Water Lotus!' The Body Shop. Online: www.thebodyshop.com.my/fijian-waterlotus (accessed 9 March 2016). 
Jolly, Margaret. 1997. 'From Point Venus to Bali Ha'i: Eroticism and exoticism in representations of the Pacific.' In Sites of Desire, Economies of Pleasure: Sexualities in Asia and the Pacific, ed. Lenore Manderson and Margaret Jolly, pp. 99-112. Chicago and London: University of Chicago Press.

Kahn, Miriam. 2011. Tahiti Beyond the Postcard: Power, Place, and Everyday Life. Seattle: University of Washington Press.

Lennon, John and Malcolm Foley. 2000. Dark Tourism: The Attraction of Death and Disaster. London: New York: Continuum.

Long, Lucy M. (ed.). 2010. Culinary Tourism. Lexington: The University Press of Kentucky.

Lutz, Catherine A. and Jane Lou Collins. 1993. Reading National Geographic. Chicago: University of Chicago Press.

MacCannell, Dean. 1976. The Tourist: A New Theory of the Leisure Class. Berkeley, CA: University of California Press.

Macleod, Donald V.L. and James G. Carrier (eds). 2010. Tourism, Power and Culture: Anthropological Insights. Bristol: Channel View Publications.

Macpherson, Cluny. 2008. 'Golden goose or Trojan horse? Cruise ship tourism in Pacific development.' Asia Pacific Viewpoint 49(2): 185-97.

Manderson, Lenore and Margaret Jolly (eds). 1997. Sites of Desire, Economies of Pleasure: Sexualities in Asia and the Pacific. Chicago: University of Chicago Press.

McCabe, Scott, Lynn Minnaert and Anya Diekmann (eds). 2012. Social Tourism in Europe. Bristol: Channel View Publications.

Michelle, Carolyn, Ann L. Hardy, Charles H. Davis and Craig Hight. 2014. 'An unexpected controversy in Middle-earth: Audience encounters with the "dark side" of transnational film production.' Transnational Cinemas, pp. 1-18.

Minca, Claudio and Tim Oakes (eds). 2006. Travels in Paradox: Remapping Tourism. Lanham: Rowman \& Littlefield. 
Mostafanezhad, Mary. 2014. 'Locating the tourist in volunteer tourism.' Current Issues in Tourism 17(4): 381-84.

Novelli, Marina (ed.). 2005. Niche Tourism: Contemporary Issues, Trends and Cases. Amsterdam and Sydney: Elsevier.

Pacific Islands Forum Secretariat. 2013. Tourism as a Pillar of Economic Growth. Nuku'alofa, Tonga, 3-5 July, Pacific Islands Forum Secretariat. Online: www.forumsec.org/resources/ uploads/attachments/documents/2013FEMM_FEMT.06.pdf (accessed 9 March 2016).

Pratt, Stephen and David Harrison (eds). 2015. Tourism in Pacific Islands: Current Issues and Future Challenges. Contemporary Geographies of Leisure, Tourism and Mobility, London and New York: Routledge.

Ringer, Greg (ed.). 1998. Destinations: Cultural Landscapes of Tourism. London and New York: Routledge.

Robertson, George (ed.). 1994. Travellers' Tales: Narratives of Home and Displacement. London and New York: Routledge.

Rojek, Chris and John Urry. 1997. Touring Cultures: Transformations of Travel and Theory. London and New York: Routledge.

Salazar, Noel B. 2010. Envisioning Eden: Mobilizing Imaginaries in Tourism and Beyond. New York: Berghahn Books.

Scheyvens, Regina. 2007. 'Poor cousins no more valuing the development potential of domestic and diaspora tourism.' Progress in Development Studies 7(4): 307-25.

- 2012. Tourism and Poverty. Hoboken: Routledge.

Shigematsu, Setsu and Keith L. Camacho (eds). 2010. Militarized Currents: Towards a Decolonized Future in Asia and the Pacific. London and Minneapolis: University of Minnesota Press.

Slatter, Claire. 2006. 'The con/dominium of Vanuatu? Paying the price of investment and land liberalisation.' Unpublished paper.

Smith, Bernard. 1960. European Vision and the South Pacific (2nd ed.). New Haven: Yale University Press. 
1992. Imagining the Pacific: In the Wake of the Cook Voyages. Carlton: Melbourne University Press at the Miegunyah Press.

South Pacific Tourism Organisation. 2012. Pacific Regional Tourism Capacity Building Programme (Inception Report and First Work Plan. South Pacific Tourism Organisation. Online: www.forumsec. org/resources/uploads/attachments/documents/EDF10_2012_ PRTCBP_Inception_Report_1st_WP.pdf (accessed 9 March 2016).

Steel, Frances. 2011. Oceania Under Steam: Sea Transport and the Cultures of Colonialism, c. 1870-1914. Manchester: Manchester University Press.

Taylor, John. 1998. Consuming Identity: Modernity and Tourism in New Zealand. Department of Anthropology, University of Auckland.

Teaiwa, Teresia. 1999. 'Reading Paul Gauguin's Noa Noa with Epeli Hau' ofa's Kisses in the Nederends: Militourism, feminism, and the "Polynesian" body.' Inside Out: Literature, Cultural Politics, and Identity in the New Pacific. ed. Vilsoni Hereniko and Rob Wilson, pp. 249-63. Boston: Rowman and Littlefield.

Trask, Haunani-Kay. 1991. 'Natives and anthropologists: The colonial struggle.' The Contemporary Pacific 3(1): 159-67.

Trask, Haunani-Kay. 1993. 'Lovely hula hands: Corporate Tourism and the prostitution of Hawaiian culture.' In From a Native Daughter: Colonialism and Sovereignty in Hawai' $i$, pp. 179-97. Maine: Common Courage Press.

Trask, Haunani-Kay. 1993. From a Native Daughter: Colonialism and Sovereignty in Hawai $i$. Maine: Common Courage Press.

Wearing, Stephen and Nancy Gard McGehee. 2013. 'Volunteer tourism: A review.' Tourism Management 38: 120-30.

Weed, Mike and Chris Bull. 2012. Sports Tourism: Participants, Policy and Providers. London and New York: Routledge.

Worldwide Independent Network of Market Research (WIN). 2014. 'End of Year Survey 2014.' Gallup International. Zurich. 30 December. Online: www.wingia.com/en/services/end_of_year_ survey_2014/8/(accessed 17 March 2016). 
This text is taken from Touring Pacific Cultures, edited by Kalissa Alexeyeff and John Taylor, published 2016 by ANU Press, The Australian National University, Canberra, Australia. 